\title{
Arginase specific activity and nitrogenous excretion of Penaeus japonicus exposed to elevated ambient ammonia
}

\author{
Jiann-Chu Chen*, Jiann-Min Chen \\ Department of Aquaculture, National Taiwan Ocean University, Keelung, Taiwan 20224, Republic of China
}

\begin{abstract}
Mass-specific activity of arginase and nitrogenous excretion of Penaeus japonicus Bate $(10.3 \pm 3.7 \mathrm{~g})$ were measured for shrimps exposed to 0.029 (control), 1.007 and $10.054 \mathrm{mg} \mathrm{l}^{-1}$ ammonia$\mathrm{N}$ at $32 \% \mathrm{~S}$ for $24 \mathrm{~h}$. Arginase specific activity of gill, hepatopancreas and midgut increased directly with ambient ammonia- $N$, whereas arginase specific activity of muscle was inversely related to ambient ammonia-N. Excretion of total- $\mathrm{N}$ (total nitrogen), organic- $\mathrm{N}$ and urea- $\mathrm{N}$ increased, whereas excretion of ammonia- $\mathrm{N}$, nitrate- $\mathrm{N}$ and nitrite- $\mathrm{N}$ decreased significantly with an increase of ambient ammonia$\mathrm{N}$. In the control solution, $P$. japonicus excreted $68.94 \%$ ammonia-N, $25.39 \%$ organic- $\mathrm{N}$ and $2.87 \%$ urea-N. For the shrimps exposed to $10 \mathrm{mg} \mathrm{l}^{-1}$ ammonia- $\mathrm{N}$, ammonia- $\mathrm{N}$ uptake occurred, and the contribution of organic- $\mathrm{N}$ and urea- $\mathrm{N}$ excretion increased to 90.57 and $8.78 \%$, respectively, of total- $\mathrm{N}$. High levels of arginase specific activity in the gill, midgut and hepatopancreas suggest that there is an alternative route of nitrogenous waste for $P$. japonicus under ammonia exposure.
\end{abstract}

KEY WORDS: Penaeus japonicus - Ammonia - Arginase activity · Nitrogenous excretion - Metabolism

\section{INTRODUCTION}

Kuruma shrimp Penaeus japonicus Bate, which is distributed in Pacific rim countries, is also found in the Mediterranean. This species matures and spawns well offshore, and the larvae develop in seawater where the salinity does not vary greatly. The postlarvae and juveniles migrate to shallow water and inhabit inshore areas and then the preadults return to the sea. $P$. japonicus is of commercial importance in Japan, China, Taiwan and even in Europe (Yu \& Chan 1986, Chen 1990). The level of salinity suitable for growth of this species is in the range 30 to $40 \%$ (Dalla Via 1986).

In an aquatic environment, the shrimp excrete ammonia, which is the primary nitrogenous waste, mainly by diffusion of $\mathrm{NH}_{3}$ and $\mathrm{NH}_{4}{ }^{+} / \mathrm{Na}^{+}$exchange across the gills. Ammonia is also formed through ammonification of organic compounds like feces and un-consumed food, during both aerobic and anaerobic

•E-mail: jcchen@ntou66.ntou.edu.tw processes. Therefore, accumulation of ammonia and its toxicity are of primary concern.

Ammonia has been reported to increase molting frequency, reduce growth, and even cause mortality of Penaeus japonicus (Wickins 1976, Kou \& Chen 1991, Chen \& Kou 1992). Following exposure to ammonia up to $10 \mathrm{mg} \mathrm{l}^{-1}$, P. japonicus accumulated ammonia and urea in the hemolymph, with suppression of ammonia excretion and an induction of urea excretion (Chen \& Cheng 1993). Suppression of ammonia excretion and induction of urea excretion have also been observed in the freshwater fish Heteropneustes fossilis following exposure to high concentrations of ammonium chloride (Saha \& Ratha 1990).

Evidence for the conversion of ammonia to urea through the ornithine-urea cycle has been observed in marine toadfish Opsanus tau and $O$. beta following air exposure and in response to high levels of ammonium chloride (Read 1971, Walsh et al. 1990); in tilapia Oreochromis alcalicus grahami, which thrives under alkaline conditions in Lake Magadi, Kenya (Wood et al. 1989); in Heteropneustes fossilis during air exposure 
(Saha \& Ratha 1987); and in rainbow trout Oncorhynchus mykiss during early life stages (Wright et al. 1995). However, nothing is known about the enzymes involved in ureagenesis of crustaceans.

In decapod crustaceans, urea levels between 8.4 and $56 \mu \mathrm{g} \mathrm{ml} \mathrm{m}^{-1}$ have been reported in the hemolymph of Carcinus maenas and Penaeus japonicus (Binns 1969, Chen \& Cheng 1993). Urea is formed either from $\mathrm{NH}_{4}{ }^{+}$ and $\mathrm{HCO}_{3}{ }^{-}$in the ornithine-urea cycle (OUC) or in the uricolytic pathway of uric acid, which is produced by the degradation of purine nucleotides by a series of enzymes (Claybrook 1983). Significant levels of OUC enzymes have been observed in the isolated liver cells of toadfish (Mommsen \& Walsh 1989). Arginase, which is the last enzyme involved in urea synthesis, has been observed in the midgut and hepatopancreas of C. maenas and Cancer irroratus (Hanlon 1975). In order to understand whether urea is formed through the OUC when shrimps are subjected to ammonia stress, we investigated the arginase specific activity and nitrogenous excretions of $P$. japonicus exposed to different concentrations of ambient ammonia.

\section{MATERIALS AND METHODS}

Test solution. Seawater pumped from the Keelung coast adjacent to the University was adjusted to $32 \% \mathrm{~S}$ with municipal water that had been dechlorinated with sodium thiosulfate, and aerated for $3 \mathrm{~d}$ before use. Ammonia test solution was prepared with ammonium chloride to produce 1 and $10 \mathrm{mg} \mathrm{l}^{-1}$ ammonia-N based on the procedure described in Chen et al. (1994a). The measured concentration of ammonia- $N$, which was determined with the phenol hypochlorite method (Solorzano 1969), was $0.029,1.007$ and $10.054 \mathrm{mg} \mathrm{l}^{-1}$ ammonia- $\mathrm{N}$ for the control, $1 \mathrm{mg} \mathrm{l}^{-1}$ and $10 \mathrm{mg} \mathrm{l}^{-1}$ ammonia- $\mathrm{N}$ treatments, respectively.

Test shrimp. Penaeus japonicus obtained from a farm in Ilan, Taiwan, were shipped to our laboratory and were kept in seawater-containing tanks with sand and gravel on the bottom, and aerated with an air-lift. The shrimp were acclimated for more than $14 \mathrm{~d}$ and fed formulated shrimp feed ( $39 \%$ crude protein) manufactured by Tairoun Products Co. (Taipei, Taiwan) once a day, but were deprived of food $2 \mathrm{~d}$ prior to experimentation. Shrimps at the intermolt stage were used for the study. The molt cycle stage was determined by the observation of uropoda in which partial retraction of the epidermis can be distinguished (Wassenberg \& Hill 1984). No distinction between sexes was made. The weight of shrimps used varied from 8 to $15 \mathrm{~g}$ with an average wet weight of $10.3 \pm 3.7 \mathrm{~g}$. No significant difference in weight was observed among treatments.
Bioassay test. For each of the 3 test solutions (control, 1 and $10 \mathrm{mg} \mathrm{l}^{-1}$ ammonia-N), there were 6 replicates with 1 shrimp in each replicate. Circular tanks (20 I capacity) were filled with $10 \mathrm{l}$ of each test solution. The shrimps were transferred from the holding tank, and exposed individually to each test solution (10 l); measurements of ammonia-N (Solorzano 1969), urea-N (McCarthy 1970), nitrite-N (Bendschneider \& Robinson 1952), nitrate-N (Wood et al. 1967) and total-N (Solorzano \& Sharp 1980) were made at the beginning of exposure and $24 \mathrm{~h}$ later. Concentration of organic-N was calculated based on the difference among total- $N$, ammonia- $N$, urea- $N$, nitrite- $N$ and nitrate- $N$. During the experiment, water temperature was maintained at $28^{\circ} \mathrm{C}$. Water $\mathrm{DO}$ (dissolved oxygen) and $\mathrm{pH}$ (mean \pm SD) were $6.58 \pm 1.13 \mathrm{mg} \mathrm{l}^{-1}$ and $8.13 \pm 0.18$, respectively, with no significant difference among the treatments.

Nitrogenous excretions. The difference in concentrations of total- $N$, ammonia- $N$, organic- $N$, urea-N, nitrite- $N$ and nitrate- $N$ between the beginning and end of the experiment was recorded. Weight-specific excretion rates of total- $N$, ammonia- $N$, organic- $N$, urea-N, nitrite-N and nitrate-N $\left(\mu g g^{-1} h^{-1}\right)$ were calculated by multiplying excretion levels by the water volume of each tank, and dividing by wet body weight and time elapsed (h).

Extraction procedure. Six shrimps from each treatment were used for the enzyme study. The shrimps were sacrificed by sampling the hemolymph. Tissues of gill, muscle, hepatopancreas and midgut were quickly removed, placed in plastic tubes and immediately deep-frozen at $-20^{\circ} \mathrm{C}$ until use for the measurement of enzyme activity. All analyses were completed within $2 \mathrm{~d}$ of collection of tissues. Tissues were thawed in ice water and an appropriate volume [volume (ml): tissue weight $(g)=10: 1$ ] of an extraction buffer containing $100 \mathrm{mM}$ tris (hydroxymethylaminomethane), $1 \mathrm{mM}$ EDTA and $1 \mathrm{mM}$ dithiothreitol (Clealand's reagent) was added to them. The final $\mathrm{pH}$ of this extraction buffer was 7.5. Phenylmethyl sulfonyl fluoride solution (in isopropanol; kept at $-20^{\circ} \mathrm{C}$ ), which is a protease inhibitor, was added to achieve a final concentration of $1 \mathrm{mM}$. Each tissue and buffer mixture was homogenized $(20 \times 60 \mathrm{~s})$ using a Model Tempest homogenizer (Virtis Co., New York, NY, USA). Homogenates were centrifuged at $13800 \times g$ for $30 \mathrm{~min}$ with a Model 5403 centrifuge (Eppendorf, Hamburg, Germany). The whole extraction procedure was performed between 0 and $4^{\circ} \mathrm{C}$. The supernatant was decanted into a chilled tube and kept in an ice bucket. For the hemolymph extraction, buffer was added immediately, and the mixture was sonicated for $3 \times 20 \mathrm{~s}$ at setting 2 with a Model XL sonicator (Misonix Incorporated, New York), and then centrifuged as above. 
Table 1. Penaeus japonicus. Mean \pm SE excretion (in $\mu \mathrm{g} \mathrm{g}^{-1} \mathrm{~h}^{-1}$ ) of total- $\mathrm{N}$, ammonia-N, organic-N, urea- $\mathrm{N}$, nitrate-N and nitrite$\mathrm{N}$ by shrimps exposed to different ambient ammonia- $\mathrm{N}$ levels. $\mathrm{n}=6$. Data in the same column having different superscripted letters are significantly different $(p<0.05)$

\begin{tabular}{|lccrrrr|}
\hline $\begin{array}{l}\text { Ambient } \\
\text { ammonia-N }\end{array}$ & $\begin{array}{c}\text { Total-N } \\
\text { excretion }\end{array}$ & $\begin{array}{c}\text { Ammonia-N } \\
\text { excretion }\end{array}$ & $\begin{array}{c}\text { Organic-N } \\
\text { excretion }\end{array}$ & $\begin{array}{c}\text { Urea-N } \\
\text { excretion }\end{array}$ & $\begin{array}{c}\text { Nitrate-N } \\
\text { excretion }\end{array}$ & $\begin{array}{c}\text { Nitrite-N } \\
\text { excretion }\end{array}$ \\
\hline Control & $37.078^{\mathrm{c}} \pm 5.197$ & $25.560^{\mathrm{a}} \pm 4.064$ & $9.416^{\mathrm{c}} \pm 0.533$ & $1.066^{\mathrm{c}} \pm 0.423$ & $0.979^{\mathrm{a}} \pm 0.218$ & $0.058^{\mathrm{a}} \pm 0.012$ \\
$1 \mathrm{mg} \mathrm{l}^{-1}$ & $50.802^{\mathrm{b}} \pm 4.503$ & $13.514^{\mathrm{b}} \pm 1.922$ & $34.030^{\mathrm{b}} \pm 3.073$ & $2.434^{\mathrm{b}} \pm 0.298$ & $0.796^{\mathrm{b}} \pm 0.120$ & $0.028^{\mathrm{b}} \pm 0.010$ \\
$10 \mathrm{mg} \mathrm{l}^{-1}$ & $103.730^{\mathrm{a}} \pm 10.717$ & $-20.747^{\mathrm{c}} \pm 2.064$ & $93.946^{\mathrm{a}} \pm 9.793$ & $9.112^{\mathrm{a}} \pm 1.604$ & $0.652^{\mathrm{c}} \pm 0.232$ & $0.020^{\mathrm{c}} \pm 0.004$ \\
\hline
\end{tabular}

Enzyme assays. Enzyme of arginase (L-arginine ureahydrolase or amidinohydrolase, EC 3.5.3.1) in the supernatant was determined for measuring urea formation in the incubation system. The arginase assay consisted of $25 \mu \mathrm{M}$ of L-arginine, $\mathrm{pH} 9.5 ; 0.5 \mu \mathrm{M}$ of $\mathrm{MnCl}_{2} ; 50 \mu \mathrm{M}$ of sodium glycinate buffer, $\mathrm{pH} 9.5$, and tissue supernatant, in a final volume of $2.0 \mathrm{ml}$. Tubes were incubated at 37 and $28^{\circ} \mathrm{C}$ for $20 \mathrm{~min}$, separately. The reaction was stopped with $2 \mathrm{ml}$ of $10 \%$ TCA (trichloroacetic acid) solution, and precipitated protein was removed by centrifuging at $4000 \times \mathrm{g}$ for 10 min at $4^{\circ} \mathrm{C}$ with a Model 5403 centrifuge. One hundred $\mu$ l of supernatant was taken and the concentration of urea was measured following the method of Rahmatullah \& Boyde (1980) using a double-beam spectrophotometer, Model U-2000 (Hitachi, Tokyo, Japan), at $525 \mathrm{~nm}$. A blank test was performed by adding sodium glycinate buffer in place of supernatant. All activities were recorded within 3 h following tissue extraction.

Enzyme units. Protein in the supernatant was estimated by Bradford's (1976) method using BSA solutions prepared with sodium glycinate buffer as standards. One unit of enzyme was defined as that amount which catalyzed the formation of $1 \mu \mathrm{M}$ of urea $\mathrm{min}^{-1}$ at 37 and $28^{\circ} \mathrm{C}$. Enzyme activity was expressed in IU (international units) $\mathrm{mg}^{-1}$ protein (specific activity).

Statistical analysis. All data were subjected to 1-way and 2-way analyses of variance (Steel \& Torrie 1980). If significant differences were indicated at the 0.05 level, then Duncan's Multiple Range test was used to identify significant differences between treatments (Duncan 1955). All statistical significance tests were at the $p<$ 0.05 level.

\section{RESULTS}

No mortality of shrimps occurred in any of the test solutions. For 2 hemolymph, 2 muscle and 2 midgut samples in $10 \mathrm{mg} \mathrm{l}^{-1}$ ammonia-N, 2 muscle samples in the control solution, 1 hepatopancreas and 1 gill sample in $10 \mathrm{mg} \mathrm{l}^{-1}$ ammonia-N, 1 muscle sample in $1 \mathrm{mg}$ $\mathrm{I}^{-1}$ ammonia- $\mathrm{N}$ and 1 midgut sample in the control solution, we were unable to detect arginase activity due to errors in processing.

Excretion of total-N, organic-N and urea-N of shrimps increased significantly with an increase of ambient ammonia- $\mathrm{N}$. In the control solution, total- $\mathrm{N}$ excretion, organic- $N$ excretion and urea- $N$ excretion were $37.08,9.42$ and $1.07 \mu \mathrm{g} \mathrm{g}^{-1} \mathrm{~h}^{-1}$, respectively (Table 1). For the shrimps in $10 \mathrm{mg} \mathrm{l}^{-1}$ ammonia-N, excretion of total- $\mathrm{N}$, organic- $\mathrm{N}$ and urea- $\mathrm{N}$ increased to ca 3, 9 and 9 times higher the level in the control solution. Ammonia-N excretion was $25.56 \mu \mathrm{g} \mathrm{g}^{-1} \mathrm{~h}^{-1}$ in the control solution, and decreased to $13.51 \mu \mathrm{g} \mathrm{g}^{-1} \mathrm{~h}^{-1}$ for shrimps exposed to $1 \mathrm{mg} \mathrm{l}^{-1}$ ammonia- $\mathrm{N}$. Net ammonia-N influx occurred for the shrimps exposed to ammonia- $\mathrm{N}$ at $10 \mathrm{mg} \mathrm{l}^{-1}$. Excretion of nitrate- $\mathrm{N}$ and nitrite- $N$ was low in the controls and decreased significantly with increase of ambient ammonia-N (Table 1).

In the control solution, ammonia- $N$ excretion, organic- $\mathrm{N}$ excretion and urea-N excretion accounted for $68.94,25.39$ and $2.87 \%$ of total- $N$ excreted by Penaeus japonicus. The contribution of ammonia-N decreased to $26.6 \%$, whereas the contribution of organic- $\mathrm{N}$ and urea- $\mathrm{N}$ increased to 66.99 and $4.79 \%$, respectively, for the shrimps exposed to $1 \mathrm{mg} \mathrm{l}^{-1}$. The contribution of organic- $\mathrm{N}$ excretion and urea- $\mathrm{N}$ excretion increased to 90.57 and $8.78 \%$ of total- $N$ for the shrimps exposed to $10 \mathrm{mg} \mathrm{l}^{-1}$ ammonia-N (Table 2).

Arginase specific activity was highest in the gill, followed by midgut, muscle, hepatopancreas and hemolymph. Arginase specific activity in the gill, midgut and hepatopancreas of shrimps increased with an increase of ambient ammonia-N. Arginase specific

Table 2. Penaeus japonicus. Percentage contribution of ammonia-N (ANE), urea-N (UNE), organic-N (ONE), nitrate$N$ (NANE) and nitrite-N (NINE) to total-N excretion of shrimps maintained at different ambient levels of ammonia-N

\begin{tabular}{|lccccc|}
\hline $\begin{array}{l}\text { Ambient } \\
\text { ammonia-N }\end{array}$ & ANE & UNE & ONE & NANE & NINE \\
\hline Control & 68.94 & 2.87 & 25.39 & 2.64 & 0.16 \\
$1 \mathrm{mg} \mathrm{l}^{-1}$ & 26.60 & 4.79 & 66.99 & 1.57 & 0.05 \\
$10 \mathrm{mg} \mathrm{l}^{-1}$ & - & 8.78 & 90.57 & 0.63 & 0.02 \\
\hline
\end{tabular}


Table 3. Penaeus japonicus. Mean $\pm \mathrm{SE}$ arginase specific activity in the hemolymph and tissues of shrimps exposed to different ambient ammonia- $\mathrm{N}$ levels. Number of samples is given in parentheses to the right of the mean. Data in the same row having different superscripted letters are significantly different $(p<0.05)$

\begin{tabular}{|lcccc|}
\hline Tissue & & \multicolumn{2}{c}{$\begin{array}{c}\text { Arginase specific activity (IU mg } \\
1 \mathrm{mg} \mathrm{l}^{-1} \text { ammonia-N }\end{array}$} & $10 \mathrm{mg} \mathrm{l}^{-1}$ ammonia-N \\
\hline Hemolymph & $37^{\circ} \mathrm{C}$ & $0.0027^{\mathrm{a}} \pm 0.0005(6)$ & $0.0025^{\mathrm{a}} \pm 0.0007(6)$ & $0.0024^{\mathrm{a}} \pm 0.0004(4)$ \\
Gill & $28^{\circ} \mathrm{C}$ & $0.0032^{\mathrm{a}} \pm 0.0013(6)$ & $0.0022^{\mathrm{a}} \pm 0.0006(6)$ & $0.0021^{\mathrm{a}} \pm 0.0004(4)$ \\
& $37^{\circ} \mathrm{C}$ & $0.1331^{\mathrm{b}} \pm 0.0279(6)$ & $0.1687^{\mathrm{b}} \pm 0.0404(6)$ & $0.2712^{\mathrm{a}} \pm 0.0220(5)$ \\
Hepatopancreas & $28^{\circ} \mathrm{C}$ & $0.0790^{\mathrm{b}} \pm 0.0185(6)$ & $0.1045^{\mathrm{b}} \pm 0.0251(6)$ & $0.1741^{\mathrm{a}} \pm 0.0086(5)$ \\
Muscle & $37^{\circ} \mathrm{C}$ & $0.0094^{\mathrm{b}} \pm 0.0017(6)$ & $0.0175^{\mathrm{a}} \pm 0.0038(6)$ & $0.0159^{\mathrm{a}} \pm 0.0066(5)$ \\
& $28^{\circ} \mathrm{C}$ & $0.0078^{\mathrm{b}} \pm 0.0024(6)$ & $0.0138^{\mathrm{a}} \pm 0.0034(6)$ & $0.0115^{\mathrm{b}} \pm 0.0037(5)$ \\
Midgut & $37^{\circ} \mathrm{C}$ & $0.0184^{\mathrm{a}} \pm 0.0049(4)$ & $0.0152^{\mathrm{ab}} \pm 0.0079(5)$ & $0.0066^{\mathrm{b}} \pm 0.0031(4)$ \\
& $28^{\circ} \mathrm{C}$ & $0.0165^{\mathrm{a}} \pm 0.0063(4)$ & $0.0101^{\mathrm{ab}} \pm 0.0055(5)$ & $0.0060^{\mathrm{b}} \pm 0.0032(4)$ \\
& $37^{\circ} \mathrm{C}$ & $0.0830^{\mathrm{b}} \pm 0.0175(5)$ & $0.1917^{\mathrm{a}} \pm 0.0813(6)$ & $0.2537^{\mathrm{a}} \pm 0.0821(4)$ \\
& $28^{\circ} \mathrm{C}$ & $0.0537^{\mathrm{b}} \pm 0.0107(5)$ & $0.1248^{\mathrm{a}} \pm 0.0503(6)$ & $0.1870^{\mathrm{a}} \pm 0.0837(4)$ \\
\hline
\end{tabular}

activities in the gill, midgut and hepatopancreas of shrimps exposed to $10 \mathrm{mg} \mathrm{l}^{-1}$ ammonia- $\mathrm{N}$ were ca 2-, 3and 1.5-fold higher than those in the control solution. Arginase specific activity in the muscle decreased significantly with increase of ambient ammonia-N. However, no significant difference of arginase specific activity was observed in the hemolymph of shrimps among the 3 treatments (Table 3 ).

\section{DISCUSSION}

Regnault (1987) reported that in decapod crustaceans, nitrogen was excreted mainly as ammonia (accounting for 60 to $70 \%$ of total excreted nitrogen) and amino acids (accounting for $10 \%$ of total excreted nitrogen), with small amounts of urea and uric acids. Ammonia- $N$ excretion by crustceans is considered to reflect protein and energy utilization under various stressful environments (Nelson et al. 1977). A decrease in ammonia- $N$ excretion with an increase of ambient ammonia observed in Penaeus chinensis, $P$. japonicus and $P$. monodon is related to retarded growth (Chen \& Nan 1992, Chen \& Cheng 1993, Chen et al. 1994a).

Ammonia- $N$ influx higher than ammonia- $N$ efflux was observed in Peneaus monodon following exposure to ammonia- $\mathrm{N}>1 \mathrm{mg} \mathrm{I}^{-1}$ by Chen et al. (1994a), and was observed in $P$. japonicus following exposure to ammonia-N $>5 \mathrm{mg} \mathrm{l}^{-1}$ (Chen et al. 1994b) and at $10 \mathrm{mg} \mathrm{l}^{-1}$ in the present study. $P$. japonicus, when exposed to increased ammonia- $N$, increased its ammonia, urea, taurine, glutamine, glutamate, arginine and total free amino acids (FAA) in the hemolymph (Chen et al. 1994b). Chen \& Chen (1996) reported that $P$, japonicus following $24 \mathrm{~h}$ exposure to ammonia- $\mathrm{N}$ as low as $5 \mathrm{mg} \mathrm{l}^{-1}$ significantly decreased hemolymph osmolality and sodium ion. Increase of
FAA is considered to play an important role in the regulation of intracellular osmolality of crustaceans during acclimation to hypo-osmotic environments (Boone \& Claybrook 1977, Gilles \& Pequeux 1983). FAA may contribute more than 10 to $60 \%$ of the intracellular osmolality (Smith \& Dall 1991). Taurine is the dominant amino acid in Northern brown shrimp Penaeus aztecus under hypo-osmotic conditions (Bishop \& Burton 1993). The fact that P. japonicus, following exposure to increased ammonia-N, increased its ammonia- $N$ excretion, with increases of hemolymph urea, taurine and total FAA, demonstrated the linkage to the intracellular osmoregulation.

Chen et al. (1994a) reported that the excretion of ammonia- $\mathrm{N}$, organic- $\mathrm{N}$ and urea- $\mathrm{N}$ accounted for 56.9 , 22.2 and $2.1 \%$, respectively, of total- $\mathrm{N}$ excreted by Penaeus monodon at $30 \%$ S. However, ammonia-N excretion was inhibited for the $P$. monodon exposed to $10 \mathrm{mg} \mathrm{l}^{-1}$ ammonia- $\mathrm{N}$, and the contribution of organic$\mathrm{N}$ and urea- $\mathrm{N}$ to total- $\mathrm{N}$ increased to 69.2 and $19.8 \%$, respectively. The contribution of the various nitrogen species to total nitrogenous excretion of $P$. japonicus is also greatly affected by different ambient levels of ammonia-N.

In crustaceans, nitrogenous excretion was affected by extrinsic factors such as temperature and salinity, and by intrinsic factors such as molt cycle, nutritional level and neuroendocrine control (Regnault 1987. Chen et al. 1994a). Since the shrimps used in our study were all at the intermolt stage and had been starved for $2 \mathrm{~d}$, they were considered to be in the same nutritional state.

In crustaceans, the metabolic pathways involved in nitrogenous excretion are catabolism of amino acid (including certain amides), deamination of purine nucleotides with the formation of ammonia, uricolysis and OUC (the ornithine-urea cycle) with the formation. 
of urea, and the degradation of nucleic acid with the formation of uric acid (Claybrook 1983, Regnault 1987). The OUC initiates with the fixation of the metabolic product of $\mathrm{NH}_{4}{ }^{+}$and $\mathrm{HCO}_{3}{ }^{-}$which is formed from $\mathrm{CO}_{2}$ through carbonic anhydrase. Walsh et al. (1989) have demonstrated that carbonic anhydrase supplies bicarbonate for urea synthesis in toadfish Opsanus beta hepatocytes. Penaeus japonicus following exposure to ammonia- $\mathrm{N}$ at $10 \mathrm{mg} \mathrm{l}^{-1}$ increased its urea excretion 9 -fold and its organic-N excretion 10 -fold, which indicates the formation of urea and other nitrogenous compounds. The fact that the specific activity of arginase, which is involved in the last step of the OUC, increased with an increase of ambient ammonia-N suggests that $P$. japonicus spent energy to produce urea and other organic nitrogenous waste to avoid the toxic accumulation of ammonia.

It is noteworthy that there is a small contribution of nitrite- $N$ and nitrate- $N$ excretion, and that these excretions decreased with an increase of ambient ammonia. Excretions of nitrite and nitrate have been also observed in Carcinus maenas at various salinity levels, and in Penaeus monodon at various ammonia-N concentrations and salinity levels (Spaargaren 1985, Chen et al. 1994a). Nitrate formation may serve in the detoxification of ammonia and the maintenance of electroneutrality inside the animals as suggested by Spaargaren (1985). Nitrate and nitrite are considered to be formed from the oxidation of nitric oxide (NO), which is produced from the conversion of L-arginine to $\mathrm{NO}$ and citrulline in the presence of NO synthase in the arginine pathway (Tayeh \& Marletta 1989, Fukuto 1995). For the final step of the OUC, arginine is hydrolyzed by arginase and produces urea and ornithine (Regnault 1987). Decreases of nitrate-N and nitrite- $\mathrm{N}$ excretions with increase of ambient ammonia- $N$ may not support the existence of the arginine pathway for shrimps under ammonia stress.

In conclusion, the present study indicated that Penaeus japonicus exposed to ambient ammonia-N as low as $1 \mathrm{mg} \mathrm{l}^{-1}$ increased its arginase specific activity in the hepatopancreas and midgut, leading to the formation of urea and other organic nitrogenous compounds, to avoid accumulation of toxic ammonia. These results also demonstrate an alternative route of nitrogenous waste for the shrimps in response to high ambient ammonia-N. Further research is needed to study the activities of enzymes such as uricase and allantoicase, involved in uricolysis, in shrimps under ammonia stress.

Acknowledgements. This paper was funded by the National Science Council (Grant No. NSC 86-2313-B019-011). We are grateful to Ms M. J. Wu for her assistance in analysis of water quality.

\section{LITERATURE CITED}

Bendschneider K, Robinson RJ (1952) A. new spectrometric method for the determination of nitrite in the sea water. J Mar Res 11:87-96

Binns R (1969) The physiology of the antennal gland of Carcinus maenas. $V$. Some nitrogenous constituents in the blood and urine. J Exp Biol 51:41-45

Bishop JP, Burton RS (1993) Amino acid synthesis during hyperosmotic stress in Penaeus aztecus postlarvae. Comp Biochem Physiol 106A:49-56

Boone WR, Claybrook DL (1977) The effect of low salinity on amino acid metabolism in the tissues of the common mud crab Panopeus herbstii. Comp Biochem Physiol 57 A: 99-106

Bradford MM (1976) A rapid and sensitive method for the quantitation of microgram quantities of protein using the principle-dye binding. Analyt Biochem 72:248-254

Chen JC, Chen CT (1996) Changes of osmotic and electrolyte concentrations in the haemolymph of Penaeus japonicus exposed to ambient ammonia. Comp Biochem Physiol $114 \mathrm{C}: 35-38$

Chen JC, Chen CT, Cheng SY (1994a) Nitrogen excretion and changes of hemocyanin, protein and free amino acid levels in the hemolymph of Penaeus monodon exposed to different concentrations of ambient ammonia- $N$ at different salinity levels. Mar Ecol Prog Ser 110:85-94

Chen JC, Cheng SY (1993) Urea excretion by Penaeus japonicus Bate exposed to different concentrations of ambient ammonia. J Exp Mar Biol Ecol 173:1-9

Chen JC, Cheng SY, Chen CT (1994b) Changes of haemocyanin, protein and free amino acid levels in the haemolymph of Penaeus japonicus exposed to ambient ammonia. Comp Biochem Physiol 109A:339-347

Chen JC, Kou YZ (1992) Effects of ammonia on growth and molting of Penaeus japonicus juveniles. Aquaculture 104 : $249-260$

Chen JC, Nan FH (1992) Effect of ambient ammonia on ammonia-N excretion and ATPase activity of Penaeus chinensis. Aquat Toxicol 23:1-10

Chen LC (1990) Aquaculture in Taiwan. Fishing News Ltd, London

Claybrook DL (1983) Nitrogen metabolism. In: Mantel LH (ed) The biology of Crustacea, Vol 5, Internal anatomy and physiological regulation. Academic Press, New York, p $163-213$

Dalla Via GJ (1986) Salinity response of the juvenile penaeid shrimp Penaeus japonicus I. Oxygen consumption and estimation of productivity. Aquaculture 55:297-306

Duncan DB (1955) Multiple-range and multiple F test. Biometrics $11: 1-42$

Fukuto JM (1995) Nitric oxide synthesis. In: Walsh PJ, Wright PA (eds) Nitrogen metabolism and excretion. CRC Press, Boca Raton, FL, p 305-328

Gilles R, Pequeux A (1983) Interaction of chemical and osmotic regulation with the environment. In: Vernberg FJ, Vernberg WB (eds) The biology of Crustacea, Vol 8, Environmental adaptation. Academic Press, New York, p $109-177$

Hanlon DP (1975) The distribution of arginase and urease in marine invertebrates. Comp Biochem Physiol 52B: 261-264

Kou YZ, Chen JC (1991) Acute toxicity of ammonia to Penaeus japonicus Bate. Aquacult Fish Manag 22:259-263

McCarthy JJ (1970) A urease method for urea in seawater. Limnol Oceanogr 15:309-313

Mommsen TP, Walsh PJ (1989) Evolution of urea synthesis in vertebrates: the piscine connection. Science 243:72-75 
Nelson SG, Armstrong DA, Knight AW, Li HW (1977) The effects of temperature and salinity on the metabolic rate of juvenile Macrobrachium rosenbergii (Crustacea: Palaemonidae). Comp Biochem Physiol 56A:533-537

Rahmatullah M, Boyde TRC (1980) Improvements in the determination of urea using diacetyl monoxime; methods with and without deprotenisation. Clin Chim Acta 107: $3-9$

Read LJ (1971) The presence of high ornithine-urea cycle enzyme activity in the teleost Opsanus tau. Comp Biochem Physiol 39:409-413

Regnault M (1987) Nitrogen excretion in marine and freshwater crustacea. Biol Rev 62:1-24

Saha N, Ratha BK (1987) Active ureogenesis in a freshwater air-breathing teleost, Heteropneustes fossilis. J Exp Zool $241: 137-141$

Saha N, Ratha BK (1990) Alteration in the excretion pattern of ammonia and urea in a freshwater air-breathing teleost, Heteropneustes fossilis (Bloch) during hyper-ammonia stress. Ind J Exp Biol 28:597-599

Smith DM, Dall W (1991) Metabolism of proline by the tiger prawn, Penaeus esculentus. Mar Biol 11:85-91

Solorzano L (1969) Determination of ammonia in natural waters by the phenolhypochlorite method. Limnol Oceanogr 14:799-801

Solorzano L, Sharp JH (1980) Determination of total dissolved nitrogen in natural waters. Limnol Oceanogr 25:751-754

Spaargaren DH (1985) The significance of nitrate in the nitrogenous excretion of Carcinus maenas. Neth J Sea Res 19:119-124

This article was submitted to the editor
Steel RGD, Torrie JH (1980) Principle and procedures of statistics. McGraw-Hill Inc, New York

Tayeh MA, Marletta MA (1989) Macrophage oxidation of Larginine to nitric oxide, nitrite and nitrate. Tetrahydrobiopterin is required as a cofactor. J Biol Chem 264: $19654-19658$

Walsh PJ, Danulat E, Mommsen TP (1990) Variation in urea excretion in the gulf toadfish Opsanus beta. Mar Biol 106: 323-328

Waish PJ, Parent JJ, Henry RP (1989) Carbonic anhydrase supplies bicarbonate for urea synthesis in toadfish (Opsanus beta) hepatocytes. Physiol Zool 62:1257-1272

Wassenberg JJ, Hill BJ (1984) Moulting behaviour of the tiger prawn Penaeus esculentus (Haswell). Aust J Mar Freshwat Res 35:561-571

Wickins JF (1976) The tolerance of warm-water prawns to recirculated water. Aquaculture 9:19-37

Wood CM, Perry SF, Wright PA, Bergman HL, Randall DL (1989) Ammonia and urea dynamics in the Lake Magadi tilapia, a ureotelic teleost fish adapted to an extremely alkaline environment. Respir Physiol 77:1-20

Wood ED, Armstrong FA, Richards FA (1967) Determination of nitrate in sea water by cadmium-copper reduction to nitrite. J Mar Biol Assoc UK 47:23-31

Wright PA, Felskie A, Anderson PM (1995) Induction of ornithine-urea cycle enzymes and nitrogen metabolism and excretion in rainbow trout (Oncorhynchus mykiss) during early life stages. J Exp Biol 198:127-135

Yu HP, Chan TY (1986) The illustrated penaeoid prawns of Taiwan. Southern Materials Center Inc, Taipei

Manuscript first received: March 18, 1997

Revised version accepted: May 6, 1997 